Journal of Sustainable Development of Transport and Logistics

journal home page: http://jsdtl.sciview.net

\title{
Prospects on Ukrainian logistics market orientation for international customers
}

\section{Olena Karpenko *, Svitlana Kovalchuk **, Oksana Shevchuk ***}

* National Transport University,

1, M. Pavlenko-Omelianovych str., Kyiv 01010, Ukraine

e-mail:tanitriel@ukr.net

Ph.D., Assoc. Prof., Department of Transport Law and Logistics

** National Transport University,

1, M. Pavlenko-Omelianovych str., Kyiv 01010, Ukraine

e-mail: swettla@ukr.net

Senior Lecturer, Department of Transport Law and Logistics

*** Ternopil Ivan Pul'uj National Technical University,

56, Ruska str., 46001 Ternopil, Ukraine

e-mail: oksana_shevchuk84@ukr.net

PhD, Senior Lecturer, Department of Transport Technology

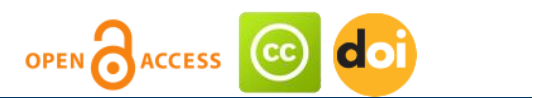

Article history:

Received: October, 2016

1st Revision: October, 2016

Accepted: November, 2016

\section{DOI:}

10.14254/jsdtl.2016.1-1.5

\begin{abstract}
The article analysed and established the current trends in the logistics environment in Ukraine. There was grounded the necessity of implementing the principles of customer management to the systems of logistic service. There was formulated conceptual mechanism of choosing the optimal carrier based on the methodology of time deviations control in the provision of transport services.
\end{abstract}

Keywords: customer-orientation, customer-management, motor transport enterprises management, quality of transport services, time deviations management.

\section{Main provisions}

One of the main sources of motor transport enterprises (MTE) are the customers. Studying their thoughts allows determining which elements of the value of transportation services and to what extent have value to them. At the same time, the object of improvements, on which administrative actions are directed, are the actual processes and the transportation system through which key elements of service value for customer and/or consumer are implemented. Thus, the conditions for the operation and development of these processes and

Corresponding author: Olena Karpenko

E-mail: tanitriel@ukr.net

This open access article is distributed under a Creative Commons Attribution (CC-BY) 4.0 license. 
systems must comply with the relevant requirements (expectations) of customer. Thereby, as one can expect a higher degree (level of satisfaction) of requirements meets, in general, relatively higher level of the value of its provision (Vorkut, T.A., 2012; Deming, E., 2007; Karpenko, O.A., Kovalchuk, S.O., \& Petunin, A.V., 2015; Popovych, P. V., 2016; Shevchuk, O.S., 2016; Popovych, P. V., Shevchuk, O.S., Matviyishyn, A.Y., \& Lototska, V.N., 2016).

Thus, the customer, based on his goals, their significance and limitations, which in turn, defined by the accepted strategy, business model, etc., should choose acceptable value of quality criteria, taking into account the corresponding value level. At the same time customer business managers must master approaches to management systems and transport processes that cannot be directly controlled, unless there used its own fleet of motor vehicles, but which efficiency should be tracked. In circumstances where the relationship "customercarrier" is distinguished, at least potentially, by a long-term and significant volume of orders, an important prerequisite to solving this problem could be the introduction of integration principles to this interorganizational relations (Vorkut, T.A., 2012; Karpenko, O.A., Kovalchuk, S.O., \& Petunin, A.V., 2015; Shevchuk, O.S., 2016). These principles, in particular, provide for coordination and cooperation, sharing profits and risks, open access to information, ensuring the functional integration and implementation of integration relations. Last are distinguished by mutual trust, cooperation and responsibility, ability to manage conflict and provide its solving as soon as possible.

Preconditions for the customer-oriented management development in the transport sector. Innovative development of transport sector is particularly important due to the integration of Ukraine into the European community. The need for competition of Ukrainian transport industry with leading foreign companies could lead to its stagnation. The cause of the problem is the low level of innovation development of Ukraine's economy as a whole. What is observed not only in small quantities of high-tech services provision in cargo transportation, but in their absence in the management of enterprises.

In the search for competitive advantage enterprises are trying to identify internal resources. Therefore, it is necessary to change the paradigm of the economic system, which sees above all to maximize profits and not customer needs satisfaction. To go on a par with foreign manufacturers we should make the consumer a key figure in commercial activities, and to direct the provision of transport services at creating consumer value by improving service quality, development of all types of innovation activities and improve the efficiency of business processes.

To achieve the above objectives, it is necessary to use the system of customer management, which is a synthesis of such administrative functions as planning, analysis, accounting, control and formation of an information system that allows, on the one hand, to increase the efficiency of internal processes in enterprises and develop their innovation, and on the other, enable consumers in the process of provision of cargo transportation.

By forming the priorities of customer's interests, Ukrainian enterprises-carriers often do not have the appropriate corporate culture and business operations, for which the ultimate goal is consumer needs satisfaction. Moreover, often customer-orientation is perceived as presence in the enterprise standards of quality service. However, not always the enterprise that clearly implementing service standards is customer-oriented. In other words, the carrier or intermediary is not trying to create conditions under which customer wants to contact them repeatedly. It also stems from the fact that the Ukrainian transport system is quite closed, so customers do not often have alternatives.

The high scientific and practical importance of studying the problems and prospects of customer management in the cargo transportation process identified the relevance of research topic. The solution to this problem is conditioned by the implementation of advanced management and marketing tools, requires high professional level of employees of companies-carriers and rigid strategy of forming a new "reality" in serving its clients.

The peculiarity of implementing customer management in the transportation process is in the delayed in time result, which may be obtained only with a systems approach. Therefore, customer-orientation should be considered as a partnership of the following participants of transport services market within each enterprise: customers, own employees, partners, owners (investors, shareholders). A rational analysis of the prospects and threats of this type of partnership depends on an adequate understanding of the impact of building the best distribution channels and methods of interaction between supplier and key customer to form a constructive dialogue between them, reduces risks, costs and promotes sales (services).

Further research requires defining the term of customer-orientation. As mentioned above, it is proposed to consider customer-orientation somewhat broader than service and service standards. Customer-orientation is a comprehensive approach to effectively manage relationships in a partnership between all stakeholders of cargo transportation, which is based on three main criteria: a key competence, key (target) customers and equality of positions (Table 1) 


\begin{tabular}{|c|c|c|}
\hline \multicolumn{3}{|c|}{ Customer management of enterprises-carriers } \\
\hline Criterion: "The key competence" & Criterion: "Equality of positions" & Criterion: "Key customers" \\
\hline $\begin{array}{l}\text { Effective management of a wide } \\
\text { range of basic and related transport } \\
\text { services }\end{array}$ & & $\begin{array}{l}\text { Joint customer inventory } \\
\text { management. }\end{array}$ \\
\hline $\begin{array}{l}\text { Technologies of creation of the } \\
\text { unique transport services }\end{array}$ & & $\begin{array}{l}\text { Shipment of goods within a } \\
\text { reasonable time for the customer. } \\
\text { Joint management of supply terms. }\end{array}$ \\
\hline $\begin{array}{l}\text { Construction of optimal transport } \\
\text { infrastructure to service the } \\
\text { maximum number of customers. }\end{array}$ & & $\begin{array}{l}\text { Peculiarities of the documents } \\
\text { registration and additional } \\
\text { reporting documentation. }\end{array}$ \\
\hline Transparent pricing policy & & Forming groups of key customers \\
\hline $\begin{array}{l}\text { Rational management of quality } \\
\text { deviations in cargo transportation } \\
\text { system }\end{array}$ & & $\begin{array}{l}\text { Individual approach in the process } \\
\text { of work with objections (claims) of } \\
\text { customers }\end{array}$ \\
\hline
\end{tabular}

From the table we can see that the criterion of "key competencies" is the ability of the enterprise-carrier to achieve certain results with the greatest efficiency. This criterion should be characterized by long term, recognized by management and applied on a regular basis. It should be noted that in many cases the key competence can be narrowed to the concept of competitive advantage that is recognized by consumer as a unique characteristics of the provider, which significantly affects his choice.

It makes no sense for each company to develop a large number of key competencies, as this will contribute to the accumulation of unnecessary information for the customer. Formulation of competence should be as clear and unambiguous to give an idea of the benefits of the company. Also, a list of key customers should be limited, depending on the scale of the enterprise-carrier.

Key customers are a limited number of customers and/or groups of customers that are a priority for the enterprise-carrier in the long term. Characteristics of key customers should be formalized by segmentation criteria such as: independence of characteristics from enterprises relation to the consumer; measurability and certainty of characteristics; independence of characteristics when used in combination (e.g., scale of business $\neq$ aggregate customer needs in cargo transportation services).

Equality of positions is a relationship between the supplier and the customer, which is characterized by lack of dominance of either party on any of the stages of relationships. Such relationships are characterized by a high degree of transparency of business processes between enterprise-carrier and the customer. The main feature of the partnership relationships is the lack of dependence on counterparty.

Thus, we can identify certain components to create customer management at enterprises-carriers:

- lack of general competencies and the availability of key competencies that are specifically developed by managers of the company;

- determination of key customers groups and identification of their unique needs;

- priority of long-term stable income to short-term profits.

However, while organizing the customer management at the motor transport enterprises one need to clearly define the difference between traditional customer service and customer-orientation of the carrier (see Table 2).

Based on data from the table we can see that the strategy of customer management does not completely ignore the traditional principles of management, but in practice should change management toolkit of cargo transportation, the nature of planning, organizational structure and methods of quality management.

In this approach, for the successful operation of enterprises-customers, there is a need to form a partnership between them and enterprises-carriers (suppliers).

Difficulty in choosing a carrier (supplier) for cargo transportation in Ukraine is due to shortage of reliable representatives on the market with a wide range of quality services and associated services. Enterprisescustomers cannot independently seek for the owners of vehicles allowed because of dynamic process of their own activities and the lack of a perfect legal framework to address issues in case of violation contract terms or other force majeure.

To understand the scope of the research we give a list of the participants of the cargo transportation services market: logistics operators, transport companies (express delivery); automobile cargo transportation forwarders; automobile cargo transportation dispatchers; carriers (individuals).

For sixteen years the cargo transportation services market has significantly increased its volume. Only the crisis years of 2009 and 2015 were problematic. Most of the market participants were formed during the late 90 s to early 2000s. This is caused by the Ukraine's economy recovery from post-crisis period of stagnation (restructuring transformation after the collapse of the Soviet Union) and the emergence of an attractive investment environment for financial and innovation investments by foreign representatives. 


\begin{tabular}{|l|l|l|}
\hline \multicolumn{1}{|c|}{ Factors } & \multicolumn{1}{|c|}{$\begin{array}{c}\text { The traditional approach to } \\
\text { management }\end{array}$} & \multicolumn{1}{c|}{$\begin{array}{c}\text { Customer-oriented approach to } \\
\text { management }\end{array}$} \\
\hline Attitude to the consumer & $\begin{array}{l}|c| \\
\text { - analysis of the enterprise activities; } \\
\text { - analysis of competitors; }\end{array}$ & $\begin{array}{l}\text { - analysis of services quality; } \\
\text { - analysis of competitive advantages of a } \\
\text { company; } \\
\text { - forming and analysis of the key } \\
\text { customer groups needs. }\end{array}$ \\
\hline Key indicators & $\begin{array}{l}\text { - volume of sales; } \\
\text { - share of the services market; } \\
\text { - number of consumers. }\end{array}$ & $\begin{array}{l}\text { - level of income from a particular } \\
\text { customer; } \\
\text { - level of enterprise services value to } \\
\text { key consumers. }\end{array}$ \\
\hline Planning approach & standard strategic and tactical planning \\
\hline Management structure & priority profit (vertical management) & $\begin{array}{l}\text { on keeping key customers and } \\
\text { increasing profit from them }\end{array}$ \\
\hline Marketing approach & additional cost item & $\begin{array}{l}\text { priority profit from a key customer } \\
\text { (horizontal management) }\end{array}$ \\
\hline $\begin{array}{l}\text { Services quality } \\
\text { management approach }\end{array}$ & Global approach ("quality loop") & local approach (deviation control) \\
\hline
\end{tabular}

During this time the cargo transportation market has changed the structure and moved to outsourcing, which was proposed by logistics operators and transport companies. Reliable market representatives (logistics operators and transport companies) acquire popularity. However, the true is the fact that in order to ensure high security of cargo transportation market leaders often distribute orders among multiple carriers (suppliers). Therefore, the development of resulting approach to effective objective assessment of enterprises-carriers is conditional. It allows you to make informed decisions that meet business objectives and customer requirements.

The analysis shows that a significant part of the tasks which are currently distinguished in the study of management processes of automobile cargo transportation can be considered as one that is aimed at solving the problems of the transport service of this in some way formed entirety of objects. It is provided that the above set of objects for transport enterprises in the central planning economy is determined defectively, and in the market conditions in the most general case, consists in a random manner.

Parameters of management processes of transport services must meet the conditions of operation of these objects and, at the same time, to ensure the effective use of relevant vehicle fleets. It is in this context can be interpreted tasks of transport routing, the choice of vehicles, forming a rational structure of vehicle fleets and so on.

Operating environment, and therefore the requirements for process control parameters of transport services for each customer normally require a certain structure of vehicle fleet, and lead to some important operational indicators of its use. Assuming that the orders are similar for the requirements of the market structure of vehicles (in general or of its certain components), the efficiency of the fleet on the values of operational indicators will be determined by the ability to provide, due to the characteristics of orders, conditions to reduce fluctuations in demand, improving territorial concentration of transportation, as well as the formation of joint shipments. Given that these orders are received from many customers directly or through forwarding companies, there is a high probability that the characteristics of orders that determine the value of operational indicators, would significantly vary. The latter creates the conditions for more efficient use of vehicles fleets and, consequently, lower transportation costs.

Transport company also in the majority of cases can refuse to perform the "unfavourable" orders for transportation or set for them relatively higher price. Under such orders, in this case, should be considered those, which characteristics cannot be effectively combined with other orders operated by transport company, at the same time, the adoption of the concept of supply chain management, as noted above, is a prerequisite to an increase in transportation performed by the orders of individual consumers, and for most cases, as a result, reducing the total number of customers served by a transport company.

It can be expected that order for transportation for each customer is such that slightly vary in the relevant characteristics. Under these circumstances, if some customers are not such that by the structure of only their own orders for transportation permit to ensure efficient use of vehicle fleet, then there is a problem of forming rational set (portfolio) of customers from the viewpoint of ensuring the effective use of vehicle fleets.

Conditions for the formation of rational portfolio of customers on the possibility to ensure effective use of vehicle fleets should be consistent with the corresponding estimates regarding risk and return ratio of the given portfolio. 
As noted above in research services quality management based on quality deviation methods is important in customer management. The essence of this approach is the fact that all the objectives facing the organization and its subsections and contained in the plans, are formalized in standards, deviations from which are found in the result of monitoring and serve as the basis for management decisions.

W. Edwards Deming expanded the scope of the Shuhart cycle use and statistical methodology of production management to sales and service delivery. He formulated the famous "Fourteen principles" of quality management and the principle of continuous quality improvement. For the first time he developed a program aimed at improving the quality of work that was based on three pragmatic axioms which synthesized the results of managers' practical activities and were accepted without proof. Therefore, the author of the research proposes to develop customer-oriented approach to the management process of selecting carriers (suppliers), based on the principles of quality management by Deming.

Evaluation of carriers (suppliers) must be carried out not only in terms of price. At this stage, it is necessary to develop a methodology for evaluation of cargo transportation service provider that would satisfy not only the requirements of the market at the B2B level (see Fig. 1), but also takes into account the wishes of the end user (i.e., the B2C level).

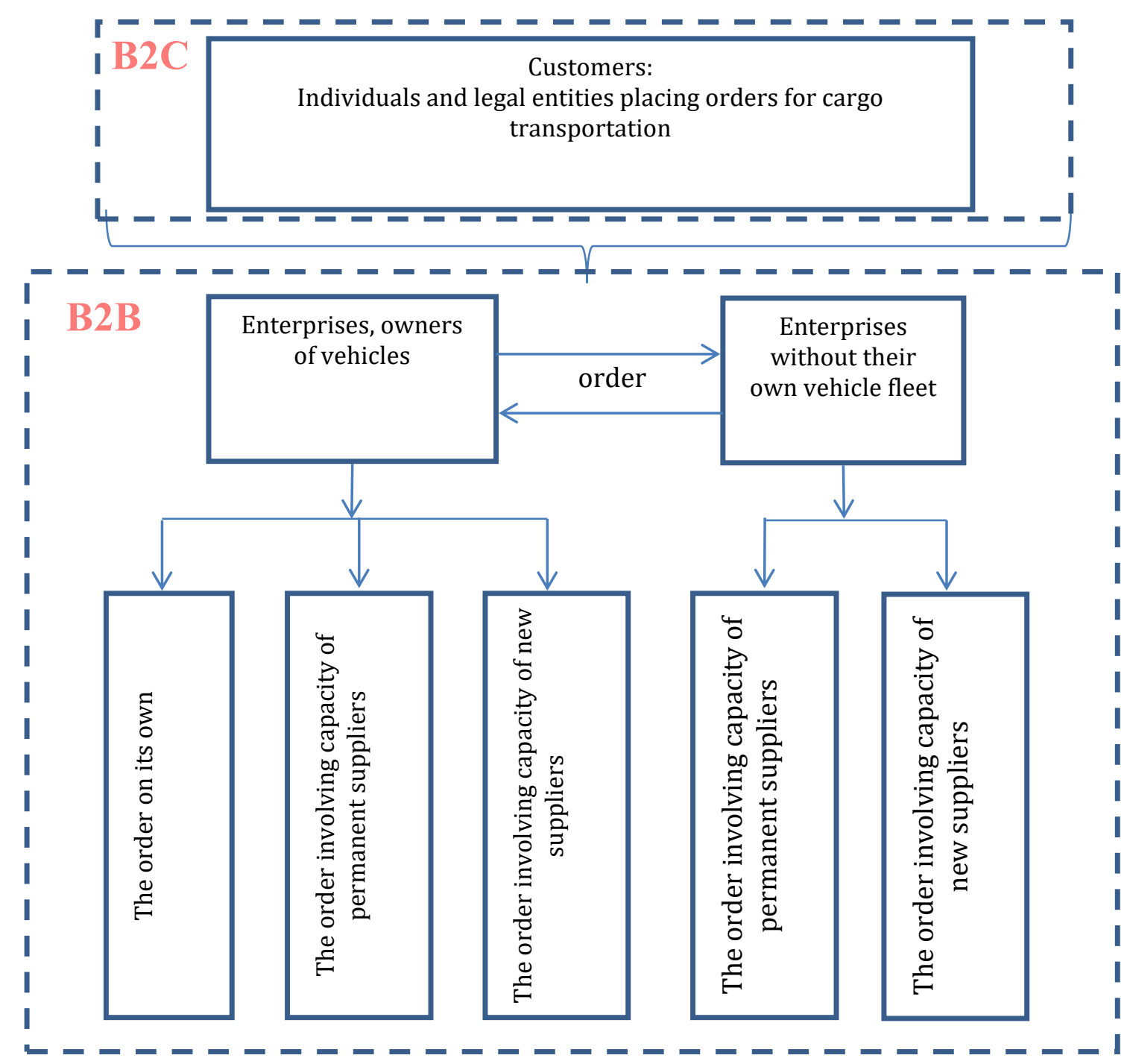

Fig. 1. Diagram of logistics market levels as an object of study

The proposed approach to the transportation quality control is formed on the detection system and random errors and deviations from the standardized parameters of quality services.

Deviations from plans and tasks arise because the process of achieving goals is not easy. The reasons for deviations may be different kinds of unforeseen situations that arise in the implementation of the plan, ignoring of necessary actions for reasons of negligence, fatigue, incompetence, bad faith, abuse, fatigue, incompetence, bad faith, abuse. 
Deviations may be different in scale and consequences. If they are small, they can be completely ignored or subordinates can independently correct the situation without bringing it to the attention of the director. With significant deviations that constitute a danger to the development of the organization or unit, management is forced to take control in their hands. To determine when management should intervene in the work deviations are classified by qualitative and quantitative parameters, terms, causes, and the degree of danger with the definition of critical values. If the last exceeded there is a need of management intervention in the management process.

Thus, the director takes over direct management activities only in important cases, based on a different experience and skills of performers. This allows him not to waste forces, time and skills, to reduce the number of decisions and to give space for subordinates' creativity. Director passes the part of his powers in the adoption of less important and critical decisions to subordinates without distancing himself from them and watching their actions and correcting if needed. To ensure the efficiency of this system, the director must trust subordinates and encourage them for their achievements at the same time not allowing shifting to him responsibility for the decision.

Deviations management is used to train employees, expand their worldview, their mastery of the activities of the organization, preparation for high positions in the future. At the same time deviations management is associated with certain difficulties and negative consequences. It cultivates among the directors and performers too formal approach, evaluation of the situation, decision-making. As a result in the shortage of sufficient information, there are non-standard situations, particularly related to psychological aspects, its implementation may be accompanied by serious obstacles.

\section{Conclusion}

It is proved that the logistics market of Ukraine requires implementation of customer management at the motor transport enterprises. It is indicated that to reach the international level, representatives of the market should adapt the mechanism of customer-oriented management to the national features of economy and to focus on managing the quality of transport services.

Implementation of deviations management requires a special accounting system of deviations and mandatory notification about them to the director, which leads to more bureaucracy in management process. Thus, deviations management in many cases based on the idea that is unusual to business life, lulls the vigilance, especially with regard to minor deviations in the surface that can have major adverse consequences.

\section{Appendix A. Supplementary material}

Supplementary data associated with this article can be found, in the online version, at http://jsdtl.sciview.net

\section{Funding}

The authors received no direct funding for this research.

\section{Citation information}

Karpenko, O., Kovalchuk, S., \& Shevchuk, O. (2016). Prospects on Ukrainian logistics market orientation for international customers. Journal of Sustainable Development of Transport and Logistics, 1(1), 27-33. doi: 10.14254/jsdtl.2016.1-1.5.

\section{References}

Deming, E. (2007). Out of the Crisis: New methods of parameters, systems and processes management. Moscow, Russia: Alpina Business Books, 2007. (in Russian).

Karpenko, O.A., Kovalchuk, S.O., \& Petunin, A.V. (2015). Problems of scientific approach in the management of suppliers. Project management, systems analysis and logistics, 16(2), 19-26. (in Ukrainian).

Popovych, P. V. (2016). Analitychni tehnologii v zabezpechenni ekonomichnoi efektyvnosti logistychnyh system [Analytical technologies to ensure economic efficiency of logistics systems]. Visnyk HNTUSG = Herald KhNTUAE, 169, 223-225. (in Ukrainian).

Popovych, P. V., Shevchuk, O.S., Matviyishyn, A.Y., \& Lototska, V.N. (2016). Issledovanie tendentsiy razvitiya rynka gruzovykh avtomobil'nykh perevozok v sovremennykh usloviyakh [Study market trends of road freight transport in modern conditions]. Bulletin of the Zhytomyr State Technological University. Series: Engineering, 2(77), 224-228. (in Russian). 
Shevchuk, O.S. (2016). Vplyv pokaznykiv efektyvnosti na bezpeku ruhu vulychno-dorozhnymy merezhamy [The impact of performance on the safety of the road network].Visnyk HNTUSG = Herald KhNTUAE, 169, 205209. (in Ukrainian).

Vorkut, T.A. (2012). Design of transport services systems in the supply chain. Kyiv, Ukraine: NTU, 2002. (in Russian).

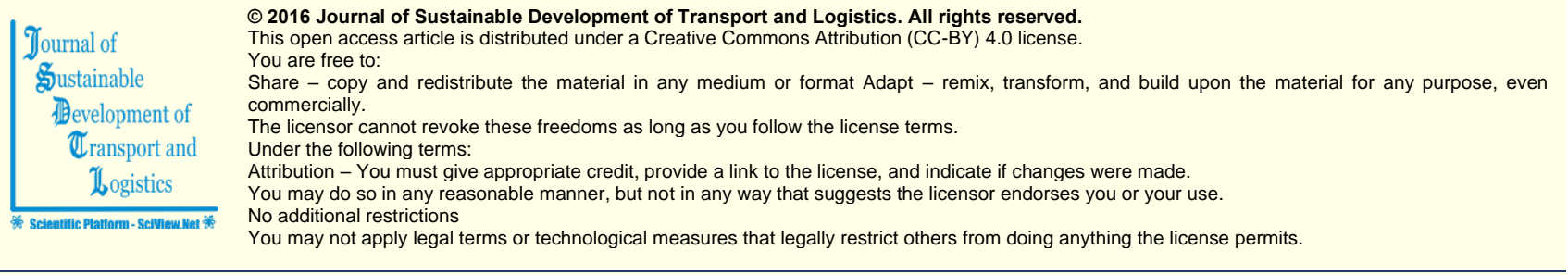

Journal of Sustainable Development of Transport and Logistics (ISSN: 2520-2979) is published by Scientific Publishing House "CSR", Poland, EU and Scientific Publishing House "SciView", Ukraine

Publishing with JSDTL ensures:

- Immediate, universal access to your article on publication

- High visibility and discoverability via the JSDTL website

- Rapid publication

- Guaranteed legacy preservation of your article

- Discounts and waivers for authors in developing regions

Submit your manuscript to a JSDTL at http://jsdtl.sciview.net/ or submit.jsdt|@sciview.net 